\title{
Severe herpetic keratitis. I: Prevalence of visual impairment in a clinic population
}

\author{
CHARLES M P CLAOUÉ, MitChEL J MÉNAGE, AND DAVID L EASTY \\ From the University of Bristol Department of Ophthalmology, Bristol Eye Hospital, Lower Maudlin Street, \\ Bristol BS1 2LX
}

SUMmARY We report a prevalence study of the best visual acuity in the affected eye of 100 selected patients with herpetic keratitis seen during a two-year period. Sixty-two patients retained an acuity of $6 / 9$ or better without requiring penetrating keratoplasty $(\mathrm{PK})$. The prevalence of reduced visual acuity severe enough to warrant PK was $33 \%$. Patients requiring PK for whom full clinical records were available suffered a mean of $6 \cdot 8$ episodes of keratitis. In this group of patients the vision of 18 fell from $6 / 6$ to $6 / 60$ over a mean period of $8 \cdot 5$ years. Once visual acuity was permanently reduced to $6 / 12,78 \%$ of patients proceeded to lose vision to $6 / 60$. Unilateral visual impairment occurs in at least a third of patients with severe herpetic keratitis. Once vision falls permanently to $6 / 12$, the long-term prognosis for vision appears to be poor.

Bristol Eye Hospital provides ophthalmic care for the City of Bristol and surrounding areas, a population of approximately 863000 . The Corneal Clinic has been established for 14 years, and all cases of severe herpetic eye disease are referred here. However, it should be noted that simple epithelial disease which heals readily with little or no visual loss is not routinely seen in this clinic.

We have surveyed the population with herpetic keratitis seen in the Corneal Clinic and recorded the best corrected visual acuities (VA). When penetrating keratoplasty was required, best VA prior to PK was recorded.

We wished to know what proportion of patients with severe herpetic keratitis lost significant VA, and we tried to ascertain how rapidly such loss occurred. To record rate of loss of VA we arbitrarily chose 6/12 and $6 / 60$, and noted the time for eyes with acuities of $6 / 6$ to fall to these levels. These levels were chosen because, if they had represented best visual acuity in the best eye, they would have prevented the patient from driving or would have allowed them to be registered as partially sighted. Since official statistics do not include unilateral loss of sight, and since the

Correspondence to C M P Claoué, FRCS, Department of Ophthalmology, St Thomas's Hospital, London SE1 7EH.
- majority of herpetic eye disease is unilateral, such patients will not appear in these statistics.

In addition we have recorded the number of recurrences of herpetic keratitis associated with a reduction in VA severe enough to warrant PK.

\section{Materials and methods}

A computerised database of all patients seen in the Corneal Clinic was begun in August 1984. It was maintained on the University main-frame Multics computer with an XQX editor. Recorded data included all diagnoses and adequate information for retrieval of hospital notes. The database was augmented and updated on a weekly basis after each clinic, and thus patients were prospectively recruited into the database.

At the end of July 1985 the database was searched 0 for all patients with herpetic keratitis. One hundred N and four patients were identified. Case notes could be located for 100 of them, and these formed the study group. The group included new patients with active keratitis during the period August 1984 to end of July 1986, old patients with recurrent keratitis, old patients with quiescent disease attending for review, pre- and postoperative patients, and those seen some time after penetrating keratoplasty.

The characteristics recorded for each patient 
Table 1 Patient characteristics recorded

All patients

Sex

Age first seen with herpetic keratitis

History of previous attacks

Right or left or both eyes affected

Disease when first seen

Subpopulation with vision reduced to at least $6 / 12$

Sex

Age first seen with herpetic keratitis

Time from onset to vision of $6 / 12$

Subpopulation with vision reduced to at least $6 / 60$

Sex

Age first seen with herpetic keratitis

Time from onset to vision of $6 / 60$

Subpopulation undergoing penetrating keratoplasty $(P K)$

Sex

Visual acuity when listed

Number of recurrences prior to listing for PK

Age at time of PK

Initial disease

Number of outpatient visits and days as in patient during the year before and two years after PK

included age at onset and at various times thereafter, sex, and whether PK was required for visual rehabilitation. A full list of characteristics is shown in Table 1.

\section{Results}

There were 51 male patients and 49 females. The mean age at onset was 38.6 years for the 68 patients who had not been treated elsewhere prior to being seen in Bristol. The left eye was involved in 62 patients and the right eye in $38(p>0 \cdot 05)$. Five patients had bilateral disease. The diagnosis of herpetic keratitis was clinical in all cases (100 patients), based on observation of a dendritic or geographical ulcer, or typical stromal disease.

The disease at presentation was epithelial (dendritic or geographical ulceration) in 41 patients, stromal in eight, and mixed in 51. At the time of the survey 62 patients had a VA of $6 / 9$ or better after medical therapy. Five patients had acuities between $6 / 12$ and $6 / 24$. All 33 patients whose VA had fallen to $6 / 36$ or worse had received a PK.

The presenting keratitis in those patients who required $\mathrm{PK}$ had been purely epithelial in 10 patients $(30 \cdot 3 \%)$, purely stromal in two patients $(6 \cdot 1 \%)$, and mixed stromal and epithelial in 21 patients $(63 \cdot 6 \%)$. Details on the number of recurrences of keratitis prior to PK were available for 20 patients $(60 \%)$; these patients had a mean of 6.8 recorded recurrences (range 3-15) before requiring PK.

Of the 33 patients who required PK 11 had no recorded VA better than $6 / 60$. These included patients refered to Bristol from elsewhere. However, 18 patients had clinical histories which recorded visual impairment from $6 / 6$ to at least $6 / 60$. There were 11 male patients and 7 female. The mean age at onset of herpetic keratitis was 51.0 years for male patients and $42 \cdot 1$ years for females. The mean time taken for vision to fall from $6 / 6$ to $6 / 60$ was 8.5 years.

In addition to the 18 patients who lost vision from $6 / 6$ to $6 / 60$ a further five lost vision to between $6 / 12$ and $6 / 36$. We were therefore able to note the rate of visual loss to $6 / 12$ in 23 patients. These patients lost vision from $6 / 6$ to $6 / 12$ in a mean of 4.8 years. Of the 23 patients who permanently lost vision to $6 / 1218$ progressed to $6 / 60$ or worse $(78 \%)$.

\section{Discussion}

Herpes simplex virus (HSV) causes disease not only when it first infects the eye, but also by producing recurrent disease (reviewed by Falcon'). Recurrent disease is thought to occur when HSV, which has established latency in the trigeminal ganglion, is shed into corneal tissue via neural pathways. Recently latency (or persistence) of HSV in ocular tissue has been reported ${ }^{2-6}$ (Claoué et al., in preparation), and clearly this may play a part in the genesis of severe recurrent disease and chronic stromal keratitis.

The pathogenic mechanisms whereby HSV produces stromal scarring and visual loss are not known. However, laboratory studies have suggested a role for T-cell mediated pathogenesis, ${ }^{7}$ and it is known that the cell population in corneal buttons removed for PK 'à chaud' contain a large proportion of cytotoxic T cells. ${ }^{89}$

The incidence of herpetic keratitis is estimated to be five patients per 10000 population per year, ${ }^{10}$ and $46 \%$ retain a visual acuity of $6 / 6$ over a period of seven years. ${ }^{11}$ Thus $54 \%$ had reduced vision and could be considered to have severe disease, including $17 \%$ whose vision fell to $6 / 18$ or worse. While we do not have a precise figure for the total number of new patients with herpetic keratitis seen during the twoyear period studied at this hospital (serving a population of 863000 ), it is known that approximately 120 new patients with herpetic keratitis are seen per year. ${ }^{12}$ This is less than that predicted from the experience of Norn. ${ }^{10}$

As in previous studies (reviewed by Tullo ${ }^{13}$ ) we find that the onset of disease is predominantly in the fifth decade of life. However, the male preponderance reported by other authors ${ }^{1014}$ was not found. This could be due to a number of factors, including a reduced frequency of severe disease in males. A number of other authors have also failed to find an obvious male preponderance among patients with stromal disease ${ }^{1819}$ or keratouveitis, ${ }^{2021}$ and we 
believe that our patients are similar to those seen elsewhere in the United Kingdom.

It is generally known that patients with herpetic keratitis may lose vision, though this particular aspect has not been extensively studied. There is no mention of the extent of visual loss in herpetic eye disease either in ophthalmic reference texts ${ }^{22}{ }^{23}$ or in specialist texts on herpetic eye disease..$^{24}$ This is in part because of the problems of following up patients for the prolonged periods required to detect visual loss, a point first made by Thygeson et al. ${ }^{25}$ in 1956. However, $17 \%$ of patients in one series had vision reduced to $6 / 18$ or worse ${ }^{11}$ and $23.4 \%$ of patients in another series lost vision to at least $6 / 12 .{ }^{26}$ In a series of 15 patients with herpetic keratouveitis $40 \%$ had a visual acuity of $6 / 12$ or worse..$^{16}$ The prognosis for patients with disciform keratitis seems to be even worse, with $30 \%$ having visual acuities of $6 / 60$ or worse at presentation, of whom the majority $(67 \cdot 5 \%)$ had the same or worse vision after treatment. ${ }^{19}$ These studies were performed by different methods from those reported here, and are also in genetically different populations. Thus it may be difficult to compare the results of other workers directly with our own.

Although we found that $33 \%$ of our patients developed visual acuities of $6 / 36$ or worse, other patients in our study group may go on to develop visual impairment, and so this figure can represent only a minimum.

The majority of patients in this study presented originally with either purely epithelial disease or mixed epithelial and stromal disease (often a small infiltrate under an ulcer). Despite treatment many progressed to significant loss of vision. However, this treatment was not standardised, and it is possible that the latest penetrating antiviral drugs such as acyclovir may prevent progression to visual impairment or alter the recurrence rate.

Those patients who regained good vision after their initial episode were observed to lose vision to $6 / 12$ in 4.8 years, and to $6 / 60$ after 8.5 years despite treatment, though therapy was not identical for all the patients. The patients with loss of vision to $6 / 60$ were on average older when first seen than the less severely affected group. It is known that stromal keratitis is commoner with increasing age. ${ }^{27}$

The finding that $33 \%$ of patients with severe herpetic keratitis require PK stresses that visual loss is frequently severe. Since these patients regained good vision and did not require simultaneous or early cataract surgery, it is reasonable to attribute the visual loss exclusively to the keratitis. Moreover, since the visual loss is most often unilateral, official statistics of blindness will not show the incidence, as they are based on the best vision in the better eye.
The number of episodes of keratitis producing a음 degree of handicap requiring keratoplasty can be as little as 3 , while the mean is only 7 , stressing the need for optimal therapy each time a recurrence occurs. It $\overline{3}$ is, however, worrying to note that $78 \%$ of patients who permanently lost vision to $6 / 12$ later progressed to $6 / 60$ or worse, suggesting that even quite mild degrees of visual loss in patients with herpetic $\frac{-}{0}$ keratitis should be considered as serious indicators of $\overline{\overline{\bar{s}}}$ prognosis. Since this is not a closed study, the figure $\widehat{D}$ of $78 \%$ can be regarded as only a minimum. There is thus a clear need for optimal medical therapy for ${ }^{\infty}$ patients with severe herpetic keratitis.

CMPC is the holder of a Wellcome Trust research fellowship. We acknowledge the help of the staff of the computer centre at theo University of Bristol, and of the medical records department at $O$ Bristol Eye Hospital. We are grateful to the following for helpful comments: Dr W A Blyth, of the University of Bristol Department of Microbiology; Professor D C Colley, of the University of Bristol $-v$ Department of Community Medicine; and Miss K E Stevenson, FRCS, of Moorfields Eye Hospital.

\section{References}

1 Falcon MG. Treatment of herpes simplex keratitis. In: Easty DL, Smolin G, eds. External eye disease. London: Butterworths, 1985: 186-214

2 Shimeld C, Tullo AB, Easty DL, Thomsitt J. Isolation of herpes simplex virus from the cornea in chronic stromal keratitis. $\mathrm{Br} J$ Ophthalmol 1982; 66: 643-7.

3 Easty DL, Shimeld C, Claoue CMP, Menage M. Herpes simplex乏 virus isolation in chronic stromal keratitis: human and laboratory studies. Curr Eye Res 1987; 6: 69-74.

4 Cook SD, Aitken DA, Loeffler KU, Brown SM. Herpes simplex응 virus in the cornea: an ultrastructural study on viral reactivation. Trans Ophthalmol Soc UK 1986; 105: 634-41.

5 Coupes D, Klapper PE, Cleator GM, Bailey AS, Tullo AB. 음 Herpes simplex in chronic stromal keratitis. Curr Eye Res $1986 ;$ 5: $735-8$.

6 Tullo AB, Easty DL, Shimeld C, Stirling PE, Darville JM. Isolation of herpes simplex virus from corneal discs of patients with chronic stromal keratitis. Trans Ophthalmol Soc UK 1985, 응 104: $159-65$.

7 Metcalf JF, Hamilton DS, Reichert RW. Herpetic keratitis in athymic (nude) mice. Infect Immunol 1979; 26: 1164-71.

8 Youinou P, Colin J, Mottier D. Immunological analysis of the cornea in herpetic stromal keratitis. J Clin Lab Immunol 1985; 17: $105-6$.

9 Youinou P, Colin J, Ferec C. Monoclonal antibody analysis of blood and cornea T-lymphocyte subpopulations in herpes simplex keratitis. Graefes Arch Clin Exp Ophthalmol 1986; 224:을 131-3.

10 Norn MS. Dendritic herpetic keratitis: 1. Incidence, seasonalo variations, recurrence rate, visual impairment, therapy. Acta N Ophthalmol (Kbh) 1970; 48: 91-107.

11 Norn MS. Dendritic (herpetic) keratitis: 2. Follow-up examinations of corneal opacity. Acta Ophthalmol (Kbh) 1970; 48:ర 214-26.

12 Easty DL. Viral diseases of the eye. London: Lloyd-Luke, 1985 을 chapter 7: 136 .

13 Tullo AB. Herpes simplex keratitis: latent and recurrent infection. In: Easty DL, Smolin G, eds. External eye disease. T London: Butterworths, 1985: 133-53.

14 Hogan MJ, Kimura SJ, Thygeson P. Pathology of herpes simplex keratoiritis. Am J Ophthalmol 1964; 57: 551-64. 
15 Dawson C, Togni B, Moore TE. Structural Changes in chronic herpetic keratitis. Arch Ophthalmol 1968; 79: 740-7.

16 Vannas A, Ahonen R, Makitie J. Corneal endothelium in herpetic ketatouveitis. Arch Ophthalmol 1983; 101: 913-5.

17 Ahonen R, Vannas A, Makitie J. Virus particles and leukocytes in herpes simplex keratitis. Cornea $1984 ; 3$ : 43-50.

18 Ohno S, Kato F, Matsuda H, Hosokawa M, Kobayachi $\mathbf{H}$. Delayed skin reactivity of patients with herpetic stromal keratitis. Ann Ophthalmol 1981; 13: 483-5.

19 Collum LMT, Logan P, Ravenscroft T. Acyclovir (Zovirax) in herpetic disciform keratitis. $\mathrm{Br} J$ Ophthalmol 1983; 67: 115-8.

20 Patterson A, Sommerville RG, Jones BR. Herpetic keratouveitis with herpes virus antigen in the anterior chamber. Trans Ophthalmol Soc UK 1968; 88: 243-9.

21 Wilhelmus KR, Falcon MG, Jones BR. Herpetic iridocyclitis. Int Ophthalmol 1981; 4: 143-50.
22 Duke-Elder S. A system of ophthalmology. London: Kimpton, 1965: 3 (1): 307-34.

23 O'Day DM, Jones BR. Herpes simplex keratitis. In: Duane TD, Jaeger EA, eds. Clinical ophthalmology. Cambridge: Harper and Row, 1985; 4: chapter 19: 1-20.

24 Blodi FC. In: Blodi FC, ed. Herpes simplex infections of the eye. London: Churchill Livingstone, 1984.

25 Thygeson P, Kimura SJ, Hogan MH. Observations on herpetic keratitis and keratoconjunctivitis. Arch Ophthalmol 1956; 56: 375-88.

26 Wilhelmus KR, Falcon MG, Jones BR. Bilateral herpetic keratitis. Br J Ophthalmol 1981; 65: 385-7.

27 Colin J, Chastel C, Coroller A, Lejeune B, Quillien MC, Querre J. Bilan de 880 cas d'herpres oculaire virologiquement confirmés. J Fr Ophtalmol 1963; 6: 877880.

Accepted for publication 8 May 1987. 